\title{
"We Will not Get Another Chance if We Lose This Battle Now": Populism on Ukrainian Television Political Talk Shows ahead of the Presidential Election in 20191
}

\author{
Kostiantyn Yanchenko \\ University of Hamburg
}

\begin{abstract}
Against a background of increasing electoral support of populist political actors in Europe and beyond, this study offers an exploratory inquiry into modern Ukrainian populism. The article examines populist communication, broadcast on the most highly rated Ukrainian television political talk shows, on the eve of the 2019 presidential election, which was completed in two rounds. A qualitative content analysis of populist communication acts $(n=283)$ shows that Ukrainian viewers were exposed to diverse political discourses containing empty, anti-elitist, emergency, and complete populism, depending on which channel(s) they watched. The dominance of one or another type of populism on the studied channels mirrors the dynamics of media-political parallelism typical of Ukrainian commercial television. The study also examines the roles of different actors-moderators, journalists, and politicians -in either restricting or facilitating populism in the talk show studios. The populismrelated reactions collected during this analysis $(n=145)$ are discussed through the prism of normative roles, with a focus on gatekeeping, interpretation, and initiation. Implications for the stakeholders involved in the process of production, moderation, and consumption of political talk shows are presented.
\end{abstract}

Keywords: populism, populist communication, Ukraine, 2019 presidential election.

INTRODUCTION

\begin{abstract}
Although numerous Ukrainian politicians have long adhered to populism as an electoral strategy, and "populism" has become a buzzword among Ukrainian journalists, political observers, and the general public, Ukrainian populism remains under-researched in academia. The only exceptions are contributions by Taras Kuzio, who has been studying Ukrainian populism for

\footnotetext{
${ }^{1}$ My great appreciation goes to Kathrin Voss and Katharina Kleinen-von Königslöw, who supervised this research project and provided invaluable advice at all stages. I am also grateful to two anonymous reviewers for their helpful and thoughtprovoking comments. Finally, I thank Alona Shestopalova, who offered professional and personal support to this study.
} 
several decades, and some other scholars such as Kurt Weyland and Tetyana Lokot. Yet there are still numerous voids in the field, and perhaps the most crucial void concerns representations of populism in the mass media. The present study fills this gap by closely examining populist communication and the way it is handled on Ukrainian television political talk shows.

The case in point is the Ukrainian presidential election, which was held in two rounds on 31 March and 21 April 2019. This event was chosen because the logic of the Ukrainian political campaign, with its main actors, milestones, and interconnections, provides a rich factual framework that can be used to interpret the findings. Besides, with old-school and newly shaped populist actors competing for power, the presidential election in 2019 deserves scholarly attention on its own. The present study focuses on political talk shows because television remains one the main sources of political information for Ukrainians (Internews Ukraine), and political talk shows play a significant role in shaping the political attitudes of Ukrainian voters (KIIS).

This study puts forward two research questions: (1) What were the features of populist communication on Ukrainian television political talk shows ahead of the presidential election in 2019? (2) What kinds of reactions and normative roles concerning populist communication were demonstrated by various actors on Ukrainian television political talk shows?

The relevance of the topic is determined by the current political situation in the world, which is witnessing a rise of populism in countries as diverse as Germany, the USA, Brazil, and the Philippines (Norris and Inglehart). Therefore, insight into the Ukrainian case would be useful for the overall understanding of populism as a phenomenon and might help to explain the specific peculiarities of populism in the Eastern European region. Special attention is paid to the role of media representatives in spreading/minimizing/restricting populism while acting as intermediaries between populist communications and their audiences.

The article proceeds as follows: a theoretical section defines the concepts used throughout the study and justifies the selections made; a methodological section operationalizes the main analytical categories and presents the measurement tools; the findings and discussion section presents the most significant results of the study and puts them into a broader perspective; and the conclusion briefly summarizes the conducted research. 


\section{THEORY}

\section{Defining Populism in the Ukrainian Political Context}

There are numerous approaches to the definition of populism. One views populism as a thin-centred ideology with the notion of popular sovereignty at its core (Albertazzi and McDonnell). Another takes a more behaviouristic stance and defines populism as a discourse (Laclau). Undoubtedly, there are other legitimate ways to address populism-for example, from the perspective of political strategies (Weyland, "Clarifying a Contested Concept"; "Neoliberal Populism") or rhetorical styles (Filc). Yet only ideological and discursive definitions are discussed further, as the ideological view is the most frequently cited (Moffitt and Tormey) and a discursive definition has been adopted in this study.

According to Cas Mudde, populism "is an ideology that considers society to be ultimately separated into two homogeneous and antagonistic groups, 'the pure people' versus 'the corrupt elite'"; such ideology argues that politics should be an expression of the volonté générale (general will) of the people (543). Importantly, Mudde emphasizes that populism can only be considered a "thin ideology" as opposed to full ideologies such as liberalism or socialism. ${ }^{2}$ The obvious merit of such a definition is its flexibility. As a thin-centred ideology, populism is not burdened with any programmatic context and hence can be associated with diverse actors such as, for example, the German AfD or French National Rally on the right and Spanish Podemos or Greek Syriza on the left of the political spectrum.

In recent years, the view of populism as an ideology has been criticized for being conceptually problematic. Thus, Paris Aslanidis rejects the whole notion of "thinness," arguing that in Mudde's logic the problem with "thinness" is unclear: "After all, a 'small' set of core attributes is always necessary in order to define something. Then racism, anti-immigration, xenophobia, sexism ... are all thin-centered ideologies by this criterion" (91). It is also argued that most ideologies have a dichotomous rather than a graded nature; in the sense that one cannot claim to be fifty percent liberal or eighty percent Marxist, one either subscribes or does not subscribe to the ideology (Aslanidis 92). On the contrary, numerous studies have shown that populism is not alien to "degreeism," meaning that populism is manifested with different strengths and intensities across various countries and time frames (see, for example, Deegan-Krause and Haughton). This leads us to the alternative, discursive approach to the definition of populism.

Populist discourse performs two basic functions: it diagnoses the problem ("elites are evil") and provides the solution ("restoration of the

2 On "thick" and "thin" ideologies, see also Freeden. 
people's authority") (Aslanidis 99). The core elements in the discursive approach are the same as the core elements in the ideological approach. The difference, though, is that populism, when being seen as a discourse, does not claim to be ideologically comprehensive but, rather, situational and instrumental, with communicative aspects in the fore. When it comes to the Ukrainian political process, the discursive approach to populism seems to be more appropriate than the ideological approach, and the reasons for that deserve a brief explanation.

The current political system in Ukraine was molded in the Soviet Union, where the only existing ideology was Communism. Among other things, it is characterized by political parties with either limited or absent ideological coherence (Whitmore). Such parties arise and disintegrate sporadically, join opportunistic alliances, and are strongly dependent on personalized leadership (Kuzio). Similar patterns can be observed at the level of individual Ukrainian politicians, most of whom change party affiliation or commitment to one or another political group many times during their careers (Sukha). While in many of Western European countries the diffusion of ideologies is a relatively new trend, the political landscape in the postSoviet region does not even imply ideologies in principle (Lankina et al.). In these conditions, it is problematic to view populism as an ideology, since neither full nor thin ideologies are identifiable in today's Ukraine.

Thus, in this study, I adhere to the discursive approach to populism that was described, among other scholars, by Pippa Norris and Ronald Inglehart: "Populism should be understood as a ... discourse reflecting first-order principles about who should rule, claiming that legitimate power rests with 'the people' not the elites" (5). ${ }^{3}$

\section{What Constitutes Populist Communication?}

What content elements are required to claim that a piece of communication is populist? An interesting attempt to answer this question systematically was undertaken by Matthijs Rooduijn. In his comparative study of six populist parties from diverse world regions and various historical periods, Rooduijn applied a "most-different" systems design to derive, as he called it, "the lowest common denominator of populism" (573). Having consistently searched for the presence of twelve populist-associated elements, he found that four elements were shared by all of the selected cases: (1) people-

\footnotetext{
3 The words "a style of" [discourse], present in the original quote, are omitted here to avoid a misreading of the word "style," which is sometimes understood as an umbrella term for certain populism-associated rhetorical elements that are not the focus of this research.
} 
centrism, (2) anti-elitism, (3) a perception of "the people" as a homogeneous entity, and (4) the proclamation of a "serious crisis" (589). While the notion of homogeneity is often embedded in the way populists refer to "the people" (see Weyland, "Clarifying a Contested Concept"; Mudde), the three other elements discerned by Rooduijn (1,2, and 4 in the above list) are incorporated in this study.

To unite the three elements of people-centrism, anti-elitism, and crisis rhetoric into an integrative frame suitable for populist communication, I followed a multi-level scheme coined by Jagers and Walgrave and later used in numerous studies (see, for example, Aalberg et al.). The scheme levels are empty populism, where people-centrism is the only required characteristic; anti-elitist populism, in which people-centrism is combined with antielitism; and exclusion populism, which is people-centrism with the exclusion of out-groups. When all elements are present within a populist communication act, this is referred to as complete populism (Aalberg et al. 16). As such an approach is based on a "thin" conceptualization of populism, a sensitivity to the diversity of populist communication is apparent.

Thus, here I shall distinguish four types of populist communication: (1) empty populism = people-centrism; (2) anti-elitist populism $=$ peoplecentrism + anti-elitism; (3) emergency populism $=$ people-centrism + crisis rhetoric; and (4) complete populism = people-centrism + anti-elitism + crisis rhetoric. The subtype exclusion populism is not included in the model as it was meant to cover the far-right discourse peculiar to many European populist actors such as Vlaams Blok, Jobbik, AfD, and FPÖ, but it was not embraced by the Ukrainian political realm in the year 2019, with its extremely low electoral support of right-wing political forces (Verkhovna Rada Ukrainy).

Instead of exclusion populism, I propose the term "emergency populism." This subtype has been derived following the logic of Jagers and Walgrave by combining people-centrism with crisis rhetoric. Crisis rhetoric is assumed to have played an important role during the 2019 presidential election campaign in Ukraine, as the main function of crisis rhetoric is to articulate and securitize social issues that are necessary for electorate mobilization (Aslanidis). Dramatizing "the fierce urgency of now" helps to overcome inertia in different types of collective action, including voting behaviour (Mayer 129). In fact, in the periods of political campaigning, crisis rhetoric constitutes one of the main facets of populist emotional appeal (Reinemann et al.). It is likely that in the conditions of war in the Donbas and economic instability in the country, Ukrainian politicians would try to make use of societal anxiety by framing the election as a turning point in history. All these factors make the inclusion of emergency populism highly relevant in this discussion of populist communication. 


\section{Dealing with Populist Communication on Television Talk Shows}

To study how populism was dealt with on Ukrainian political talk shows in 2019, I draw from the framework proposed by Wettstein and others. They distinguish three principal roles that news media-or, in this case, talk show participants-may take with respect to populist communication: gatekeeping, interpreting, and initiating (Wettstein et al. 478-80). This framework has been chosen for the present analysis because it is comprehensive and, hence, appropriate to describe a relatively unstudied political context. It builds upon a large and diverse body of literature and considers contributions from the domains of journalistic role performance (Deuze), media populism (Krämer), and framing theory (Goffman) (for a more detailed discussion of the framework see Wettstein et al.). The present study attests to the comprehensiveness of the populist communication framework; indeed, the collected data did not contain any reactions to populist communication that would not fit into one of the three roles of gatekeeping, interpreting, and initiating. Since the framework was initially designed to analyze print media, the peculiarities of television as an audiovisual media channel have been taken into consideration.

\section{Gatekeeping}

The idea that in conditions of an information surplus it is neither possible nor necessary to tell the public everything has been a useful gatekeeping theory since the 1950s (Shoemaker and Vos; Breeze). When gatekeeping, specific items of information are selected. Such selection opens the "news gates" to certain messages but not to others, based on numerous factors such as personal preference, professional experience, institutional influence, and bias. The gatekeeping principle extends to the selection of topics and speakers and to the adoption of other communication-related decisions. Gatekeeping is not an either/or procedure (Donahue et al.). By deciding upon the space and placing of materials in the press or their airtime and duration on the radio and television, media workers may open the news gates to a certain extent, i.e., adjust them. Finally, gatekeeping is a multifaceted phenomenon executed by individual media workers at the micro level, supervised by media company management at the meso level, and influenced by the features and tendencies of the specific media system at the macro level. Thus, relatively free and stable media environments contribute to a more autonomous gatekeeping process, while in more authoritarian contexts the impacts of media owners, political elites, and other stakeholders may result in restricted and/or distorted information flow.

On political talk shows, gatekeeping is implemented in two phases. In the organizational phase the media producers decide which topics to raise 
(and which to let lie), which guests to invite (and which to eschew), and what the opinion balance and overall structure of the program will look like. In the live phase, gatekeeping is implemented during the broadcast by talk show moderators who can grant or remove access to the microphone, determine the sequence and duration of speeches, and interrupt the talk show with advertising blocks. Depending on the talk show format, other talk show actors can also participate in gatekeeping.

\section{2. $\quad$ Interpreting}

Media workers can provide positive or negative evaluations of populist actors and their messages (Wettstein et al. 479). Common reasons for a positive evaluation of populism include commercial considerations (Haller), personal advocacy of certain topics and ideas (Ojala and Pöyhtäri), and the impact of media-political parallelism. Conversely, media workers may choose to evaluate populism negatively, either following the ideals of socially responsible journalism (Hallin and Mancini) or as a reaction to systematic populist attacks on the media as an institution (Esser et al.).

I shall add one more type of evaluation by the media of populist actors and their messages. A critical evaluation is needed to distinguish between emotional and rational (argument-based) evaluations, as well as personal (aimed at the speaker) and impersonal (aimed at the message) evaluations. Such a separation is useful in assessing the impartiality of media reactions to populism. The notion of a critical evaluation takes its root from the concept of "watchdog journalism" and implies a careful or even skeptical attitude to any political message (Ojala and Pöyhtäri). By acting as watchdogs, media workers try to make sure that the public receives trustworthy information and is not being manipulated.

Talk show participants act as interpreters when they react positively or negatively to populist messages and when they demonstrate critical thinking by questioning particular statements, asking for evidence, providing contra arguments, or pointing to manipulations. On television political talk shows, the interpreting role includes both verbal and non-verbal reactions and can be implemented only during the actual broadcast.

\section{Initiating}

The essence of this role, as explained by Wettstein and others, is as follows:

In their role as originators of messages, journalists may actively engage in populist coverage independent of any relationship to populist political actors. Triggered by a role understanding as voice of the people or as a countervailing power to governments, parties, and the political 
establishments ... journalists may engage either in advocative or peoplecentrist media populism and/or in conflictive or anti-elitist media populism. (479)

Journalists are either interpreters or initiators of populism, depending on whether their statements are reactions to a populist communication or self-sufficient populist messages. In televised political talk shows, media representatives act as initiators of populist communication when they appeal to "the people" (those in the studio or the viewing audience), when they ask questions "on behalf of the people," or when they claim to represent "the ordinary people" during discussions. Media producers can also initiate populist communication when they repeatedly focus on topics ranking high in populists' agendas or when they invite guests who frequently disseminate populism in their speeches.

\section{METHODOLOGY}

\section{Sample}

Talk shows for the study of populist communication were selected by purposeful sampling, a type of non-probability sampling used to identify "information-rich cases for the most effective use of limited resources" (Palinkas et al. 534). Specifically, the sample was constructed following the criterion-i approach (Patton), which focuses on similarities between the units and helps to sample the cases that meet some predefined criteria of significance (Palinkas et al. 534). In this case, the criteria of significance were as follows:

(1) The selected TV channels were all commercial, which is an important condition for their comparability (Mazzoleni). Half of them (112 Ukraine and Priamyi) represented information channels (I) and another half $(1+1$ and ICTV) represented general channels (G). These types of television channels are the main producers of socio-political content, including political talk shows, in the commercial segment of Ukrainian television.

(2) Only TV channels and talk shows with high popularity ratings were targeted, because a talk show's popularity is positively correlated with its attendance by top politicians, which allows the most indicative political messages to be identified (Shkarpova et al.). 112 Ukraine and Priamyi were, respectively, the first and second most highly rated channels in the information category in the first quarter of 2019 , and 
$1+1$ was the second most highly rated channel in the general category. (The most highly rated channel in the general category, Ukraina, did not broadcast any political talk shows in the studied period.) ICTV was not the most popular channel in the first quarter of 2019, but it was sampled to include Svoboda slova (Freedom of Speech), a talk show with particularly high ratings on the eve of the presidential election (see Table 1).

(3) The diversity of the talk show sample with respect to media-political parallelism is acknowledged to be an important factor in the Ukrainian media landscape (Ryabinska). Here, I primarily refer to the narrow definition of media-political parallelism as a characteristic of the media system manifested in the presence of organizational connections between media and political actors (Hallin and Mancini 28). Such connections may affect the media content and the professional autonomy of the journalists, and endanger both internal and external pluralism (Hallin and Mancini 29). This is exactly what was taking place on the sampled TV channels. Extensive monitoring of media coverage of the Ukrainian presidential election campaign 2019 revealed that Ukrainian media "showed ... more or less open sympathies towards particular candidates and political subjects"; "candidates' appearances in the news and current affairs programmes ... [did] not appear to be always determined based on newsworthiness, but possibly by the interests of [media] owners"; and "clear demonstration of political preference in favor or against a particular candidate reflected in the format and behavior of the hosts reduce[d] ... [the] value [of the talk shows] for voters" (Burmahin et al. 3-4). With that in mind, I have deliberately targeted TV channels affiliated with different interest groups so that all the key political actors would be represented. Besides, this ensured we would be allowed to analyze Ukrainian populism in its diversity. More details about the characteristics of the selected TV channels, including the ownership structure and ratings, can be found in Table 1. 
Table 1: Additional information regarding TV channels and talk shows that were sampled to reflect populist communication.

\begin{tabular}{|c|c|c|c|c|c|}
\hline $\begin{array}{l}\text { TV Channel } \\
\text { (thematic } \\
\text { group) }\end{array}$ & $\begin{array}{l}\text { Rat \% / } \\
\text { Shr \% } \\
\text { (ranking } \\
\text { in the } \\
\text { thematic } \\
\text { group) }\end{array}$ & Owned by & Influenced by & $\begin{array}{l}\text { Associated } \\
\text { Candidate } \\
\text { (place in } \\
\text { Round I) }\end{array}$ & $\begin{array}{l}\text { Talk Show } \\
\text { (audience, } \\
\% \text { ahead of the } \\
\text { election) }\end{array}$ \\
\hline$\overline{1+1(G)}$ & $\begin{array}{l}1.84 / \\
10.06(2)\end{array}$ & $\begin{array}{l}\text { Ihor } \\
\text { Kolomois'kyi }\end{array}$ & $\begin{array}{l}\text { Ihor } \\
\text { Kolomois'kyi }\end{array}$ & $\begin{array}{l}\text { Volodymyr } \\
\text { Zelens'kyi (1) }\end{array}$ & $\begin{array}{l}\text { Pravo na vladu } \\
\text { (Right to Power) } \\
(\approx 15.0)\end{array}$ \\
\hline Priamyi (I) & $\begin{array}{l}0.23 / \\
1.25(2)\end{array}$ & $\begin{array}{l}\text { Volodymyr } \\
\text { Makeienko }\end{array}$ & $\begin{array}{l}\text { Petro } \\
\text { Poroshenko }\end{array}$ & $\begin{array}{l}\text { Petro } \\
\text { Poroshenko (2) }\end{array}$ & $\begin{array}{l}\text { Ekho Ukrainy } \\
\text { (Echo of Ukraine) } \\
(\approx 3.5)\end{array}$ \\
\hline 112 Ukraine (I) & $\begin{array}{l}0.34 / \\
1.85(1)\end{array}$ & $\begin{array}{l}\text { Taras } \\
\text { Kozak }\end{array}$ & $\begin{array}{l}\text { Viktor } \\
\text { Medvedchuk }\end{array}$ & $\begin{array}{l}\text { Iurii } \\
\text { Boiko (4) }\end{array}$ & $\begin{array}{l}\text { Pul's (Pulse) } \\
(\approx 5.9)\end{array}$ \\
\hline $\operatorname{ICTV}(G)$ & $\begin{array}{l}1.23 / \\
6.74(4)\end{array}$ & $\begin{array}{l}\text { Viktor } \\
\text { Pinchuk }\end{array}$ & $\begin{array}{l}\text { Viktor } \\
\text { Pinchuk }\end{array}$ & $\begin{array}{l}\text { no systematic } \\
\text { evidence }\end{array}$ & $\begin{array}{l}\text { Svoboda slova } \\
\text { (Freedom of } \\
\text { Speech) } \\
(\approx 20.0)\end{array}$ \\
\hline
\end{tabular}

After sampling the channels and talk shows, two entire episodes of each talk show were selected for the analysis of populist communication content. As the presidential election in 2019 comprised two rounds, it was decided to sample the last talk show episodes before the first and the second election rounds in order to cover more candidates and to reflect on the growing societal tensions on the eve of the second election round. The episodes were accessed through the YouTube archives of the respective TV channels, downloaded, and stored offline. The total duration of the analyzed material (8 episodes) was approximately 24 hours. Obviously, such a sample size is not sufficient to inform a long-term discussion of Ukrainian populism. However, it serves well in capturing the trends of populist communication on the most highly rated political talk shows produced ahead of the presidential election in 2019.

At this point, one might reasonably wonder why the Ukrainian public broadcaster (UA: PBC) with its political talk show Zvorotnyi vidlik (Countdown) was not included in the sample studied here; this situation requires a brief explanation. First, differences in formats, funding models, political parallelism dynamics, and professional challenges faced by producers and journalists make it problematic to compare populist communications on commercial television with populist communications on public television. For instance, the rationales behind populist communications discussed in the theoretical section are inherently different for public and commercial TV channels. Second, during the election 
campaign in 2019, Countdown did not manage to attract any of the top candidates (Volodymyr Zelens'kyi, Petro Poroshenko, Iuliia Tymoshenko, and Iurii Boiko) to the studio, and the last Countdown episode before the first round of the election featured no politicians at all. The above-mentioned candidates took the first four places in the election and were the most mediatized politicians in the analyzed time frame. Thus, if Countdown was to be included in the analysis, it would have made the sample less representative with respect to the overall political discourse.

\section{Measurement}

Table 2: The coding frame for qualitative content analysis

\begin{tabular}{lll}
\hline Category & Code & Subcode \\
\hline $\begin{array}{l}\text { I. Type of PCA (Populist } \\
\text { Communication Act) }\end{array}$ & 1A (empty populism) \\
& 1B (anti-elitist populism) \\
& 1C (emergency populism) \\
& 1D (complete populism)
\end{tabular}

\section{Features of PCA}

Topic of the act

Timing of the act

Duration of the act

Who disseminates the PCA?

\author{
(descriptive code: e.g., "war") \\ (hh:mm:ss-hh:mm:ss) \\ (mm:ss)
}

2A politician

2B another guest

2C talk show host

2D journalist

\section{Reaction(s) to PCA}

Timing of the reaction

Who reacts to the PCA? (hh:mm:ss-hh:mm:ss)

$$
\begin{aligned}
& \text { 3A talk show host } \\
& \text { 3B journalist } \\
& \text { 3C politician } \\
& \text { 3D another guest }
\end{aligned}
$$

(name and affiliation) (position) (name) (name and affiliation)

(name) (name and affiliation) (name and affiliation) (position) 
Table 2 cont.

\begin{tabular}{l} 
Category \\
\hline IV. The type of reaction to \\
the PCA
\end{tabular}

4A gatekeeping

$\begin{array}{ll} & \mathbf{5 A} \text { gate } \\ & \text { opening } \\ & \text { (excluded } \\ \text { during } \\ \text { analysis) } \\ \text { 5B gate } \\ \text { closure }\end{array}$

6A

positive evaluation

6B

negative evaluation

6C critical

4C initiating

evaluation

(yes, if 2C or 2D present)

Table 2 presents the coding frame used to analyze the selected talk show episodes. The main categories in Table 2 (in bold) specify aspects of the information of interest in the context of the research questions. The coding was done in a prearranged Excel table where the column headings corresponded to the codes and subcodes from the coding frame and the line captions indicated the number of the case (individual act of populist communication).

The category "Type of PCA" aimed to attribute each populist communication act (PCA) to one of the subtypes of populist communication. Since the minimalist approach to the definition of populism was employed (people-centrism is a sufficient condition), this procedure coincided with the primary identification of the PCA. Thus, the PCA was regarded as present if the talk show participant exhibited proximity to "the people" by appealing to them and/or talking about them positively, knowingly, or sympathetically. The reference to the people might have been expressed in such words as "(the) people, (the) public, (the) citizen(s), (the) voter(s), (the) taxpayer(s), (the) resident(s), (the) consumer(s), (the) population" (Jagers and Walgrave 323). If anti-elitist and/or crisis messages were not mentioned in the same passage, code $1 \mathrm{~A}$ (empty populism) was applied. 
Code 1B (anti-elitist populism) was applied when the talk show participant combined a positive evaluation of "the people" and/or an appeal to them with a condemnation of the "elite." The elite here might have been individual politicians and political parties, civil servants, national and international institutions, judges, the media, experts, or intellectuals (Norris and Inglehart 5). The condemnation, in turn, was understood as an expression of strong disapproval, which at an empirical level might be described as "corrupt, fraudulent, dysfunctional, treasonous, arrogant, immoral" (Norris and Inglehart 5).

Code 1C (emergency populism) was applied when the talk show participant combined a positive evaluation of "the people" with a proclamation of an actual or forthcoming crisis that will pose a threat to said people. The crisis was understood as a time of intense difficulty, trouble, or danger and might have been related to security, political, economic, cultural, or any other aspect of life. Thus, crisis rhetoric was regarded as such when a specific situation was characterized by the talk show participant as being unacceptable, dangerous, catastrophic, unpredictable, or alarming (Rooduijn 576). Code 1D (complete populism) was applied when the conditions for both codes $1 \mathrm{~B}$ and $1 \mathrm{C}$ were met.

The codes within categories "Features of PCA" and "Reaction(s) to PCA" deal with manifest metadata, which can be obtained in open sources.

\section{Role(s) toward PCA}

Code 4A (gatekeeping) was applied when the talk show participant either prevented or promoted the spread of the PCA by the disseminator. The prevention of a PCA (subcode 5B, gate closure) could be exercised, for instance, through interruption of the speaker, a change of topic or a change in the focus of the discussion, an appeal to the speaker with a request to return to the point or to be more specific, or an invitation to other guests to join the discussion. The gate opening subtype was removed from the frame at the beginning of the analysis since it turned out to be difficult to operationalize and keep track of in a systematic manner.

Code $4 \mathrm{~B}$ was applied when the talk show participant evaluated the speaker who was articulating the PCA or the PCA itself. A 6A positive evaluation was applied when the speaker and/or the PCA were verbally or non-verbally supported by another talk show participant. This could be manifested in approving words, gestures, or facial expression. In turn, 6B was applied when the opposite reaction took place. Subcode 6C was applied when the critical evaluation or questioning of certain statements was (1) not emotional but pragmatic (based on rational argumentation); or (2) related exclusively to the PCA, not to the speaker disseminating it. 
Subcode 4A (initiating role) was applied when either the talk show moderator(s) or the invited journalist(s) were issuing a PCA irrespective of the politicians and other guests. Empirically, these data are situated in the second category (the question "Who disseminates the PCA?"). That is why it was possible to apply code $4 \mathrm{C}$, based on the presence of codes $2 \mathrm{C}$ and/or 2D, within the PCA under analysis. As can be seen, the frame was designed so that coding would take place only when a given statement was classified as a PCA. This helped to reduce the amount of analyzed material to the actual populist communication.

The semantic approach was employed to code the ideas surrounding the sentences containing specific PCA(s). Thus, a populist communication act was considered finished when the disseminator brought the thought containing the populist element(s) to its logical conclusion and moved on to the next subject or to another aspect of the same issue. The end of the thought was usually indicated by the compositional resolution of the text and the presence of transitional and/or conclusive words and collocations. Such an approach to data segmentation is rooted in textology and is often used in qualitative methods of linguistic analysis. To avoid potential inconsistencies that could arise using such a coding method, the codes were summarized using two different techniques, one of which was not sensitive to the length of the speaker's statements. The coding frame suggested the use of deductive codes and an analysis of both quantitative and qualitative data. Since the main categories (I and IV) implied work with latent meanings and required considerable interpretation, qualitative content analysis has been used in this study (Schreier).

FINDINGS AND DISCUSSION

\section{Populism on Ukrainian Political Talk Shows}

Figure 1 shows the share of populist communication on the studied talk show episodes before the first and second rounds of the presidential election in 2019. The chart demonstrates that populist communication was present to some extent in all the analyzed episodes irrespective of the television channel or broadcast date, and its proportion varied both across and within the talk shows. Among all the sampled material, the highest level of populist communication was scored by the first episode of the talk show Freedom of Speech. This was likely due to the failure of the channel to provide an opinion balance in the studio: all of the invited guests were somehow affiliated with the speaker Poroshenko, whereas the two others, Ruslan Koshulyns'kyi and Valentyn Nalyvaichenko, did not have support groups. In comparison, a previous pre-election episode on 18 March 2019-featuring Iuliia 
Tymoshenko, Anatolii Hrytsenko, and Oleksandr Vilkul as the main speakers-drew more guests, some of whom can be considered politically neutral and others linked to the speakers' political rivals. The talk show Right to Power received the lowest proportion of populist communication before the first round, mainly because of the large number of journalists, who tended to counterbalance the speeches of the politicians.

\section{Figure 1: Percentage of populist communication on each listed talk show ( $n=283)$.}

$\square$ Freedom of Speech $\square$ Pulse $\square$ Echo of Ukraine $\square$ Right to Power

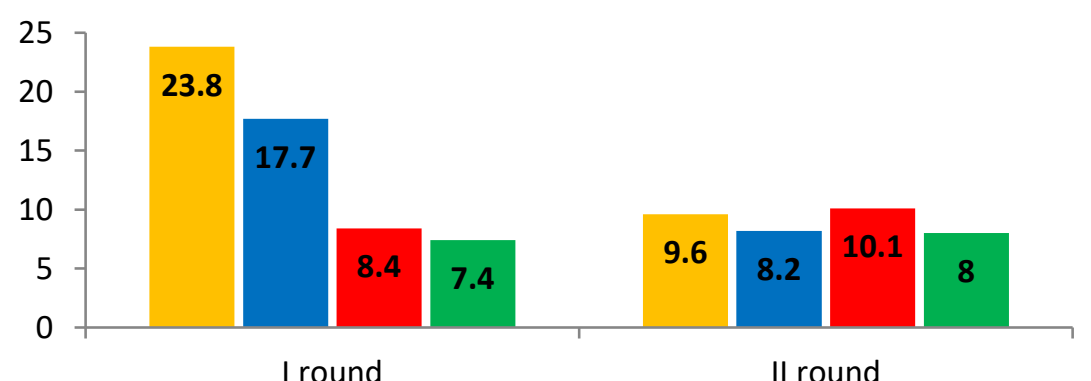

It can also be seen that two talk shows-Freedom of Speech on ICTV, which was reported to be relatively impartial during the presidential campaign, and Pulse on 112, which was reported to support candidate Boiko, who did not qualify for the second round of the election-showed a considerable decline in the share of populist communication between the first and second rounds (Burmahin et al.). Contrary to this trend, the proportion of populism increased slightly on Echo of Ukraine (Priamyi) and Right to Power $(1+1)$, on the channels reported to support the candidates who qualified for the second election round-Poroshenko and Zelens'kyi, respectively. Such patterns signal the potential impact of political parallelism on the amount of populism in the studios.

Apart from calculating the share of populism for each of the talk show episodes, the material was also examined for the intensity of populist communication. This approach is expedient since diverse speakers have different styles of public performance-which, among other things, is expressed in how verbose they are. For example, ten randomly sampled PCAs by Poroshenko lasted 4:39 on Freedom of Speech (round I), while it took only 2:56 for Zelens'kyi to make the same number of populist statements on Right to Power (round II). Such a difference is mainly due to Zelens'kyi using less complex semantic structures than Poroshenko. The 
variation in speakers' verbosity has to be considered because when one codes not just the occurrence of certain lexemes in the text but the integrity of speakers' thoughts, the proportion of populist communications gets overstated for speakers who are more verbose than the others. Thus, measuring the intensity of populist communication allows controlling for this factor.

Figure 2 shows the intensity of populist communication, that is, how many PCAs were disseminated on each episode of the studied talk shows, per ten minutes on average. When this graph is matched to Figure 1, it becomes clear how significant verbosity is. For instance, Right to Power had the lowest share of populism before the second round but simultaneously scored the highest number of PCAs per ten minutes on the same program. The opposite trend can be seen in the case of Echo of Ukraine, where the talk show participants rarely used populist elements on the eve of the second round, but when they did, those were "grand messages" loaded with plenty of meaning. Meanwhile, On Pulse was a step down in the amount of populist communication between the two rounds (Figure 1), and totally level when another type of measurement is applied (Figure 2).

\section{Figure 2: Intensity of populist communication on each talk show, PCAs per $10 \mathrm{~min}(\mathrm{n}=\mathbf{2 8 3})$.}

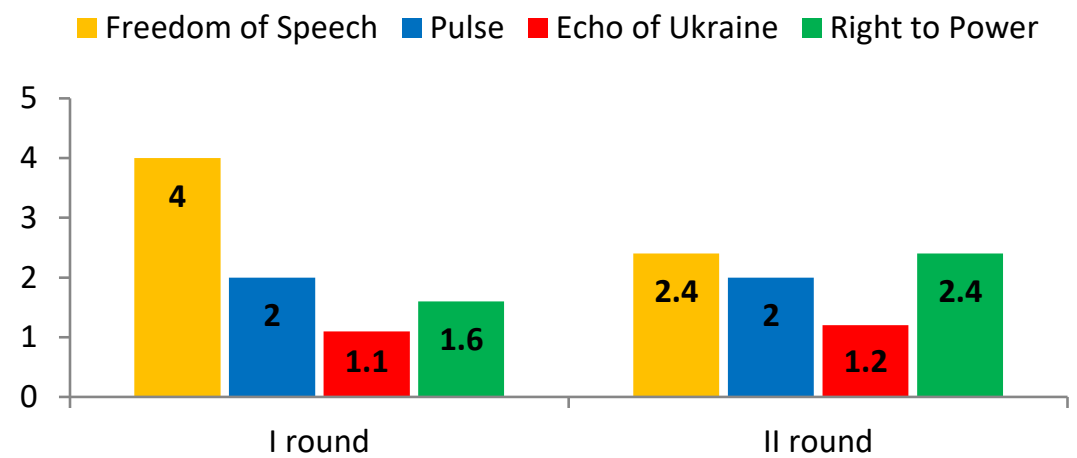

The provided comparisons reveal that on the studied talk shows, there were two distinctive ways of disseminating populism. One suggested using key populist elements as connecting links to convey complex political messages; the other implied more frequent usage of populist elements in the form of slogans and formulas, less sophisticated but more comprehensible. Indeed, literature on the perception of long versus short semantic constructs states that the simplicity of political communication tends to correlate positively with the ability of the electorate to better comprehend political parties' policy positions (see Bischof and Senninger). This explains why 
many populist actors-including Zelens'kyi-increasingly, and not without success, adhere to colloquial style while communicating with citizens (Ernst et al.).

Moving further, Figure 3 shows the share of different types of populist communication on the studied talk shows (average for both episodes). In the first place, the graph provides additional information to the discussion about populism and the speakers' verbosity. Consider the following observed patterns. Right to Power had the lowest proportion and the highest intensity of populist communication before the second round, and it was also the talk show with the highest share of empty populism, while Echo of Ukraine had the highest proportion and the lowest intensity of populist communication before the second round and scored the highest in complete populism. Obviously, such patterns are not accidental. It takes more time to combine people-centrism, anti-elitism, and crisis rhetoric within one thought than just to appeal to "the people" while speaking. It means that the verbose political communication style not only increases the proportion of populism but also facilitates the usage of complete or thick populism, which has greater mobilizing potential and is often associated with the construction of out-groups and hate speech (Breeze). This once again emphasizes the importance of political talk shows being structured strictly nondiscriminatively, as well as imposing reasonable time limits for each of the speakers.

Figure 3: Average share of PCA types on each talk show, \% $(n=283)$.

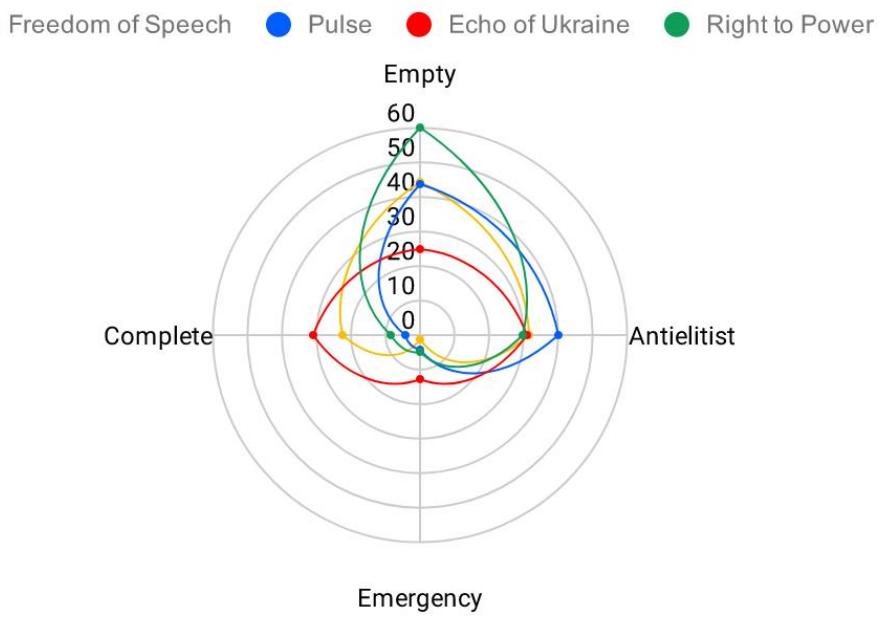

Figure 3 reveals some other notable trends. Empty populism was the most common type of populist communication on almost all of the studied 
talk shows. This is not surprising, considering that the sampled talk shows were broadcast during the peak of the election campaign-a time when direct reference to "the people" is increasingly used by all political actors, but especially populist ones (Groshek and Koc-Michalska). The exception was Echo of Ukraine, where none of the presidential candidates or highranking politicians were present on the sampled episodes; this explains the lower rates of people-centrism on that talk show. Experts and low-ranking politicians do not praise "the people" on a regular basis simply because they are not the ones who need "the people's" votes. On the other hand, Ukrainian politicians appeal to "the people" so often and in such diverse situations that it is not the political content being sold in a populist wrapping but rather populism itself as the ultimate message being targeted at voters regardless of their political preferences.

Anti-elitism was another prominent populist element on the eve of the presidential election, even though it meant different things for different actors. For Poroshenko and his supporters, referenced elites meant primarily two things: (1) the oligarchs connected to Zelens'kyi-"revengeseekers," "cynics," "technocrats"; (2) Boiko and his team-"the Kremlin's representatives in Ukraine," "the fifth column," etc. For most other political actors, the elite meant president Poroshenko and his team- "the corrupt authorities," "parliament without popular support," "the establishment." Knowing this, it is clear why anti-elitism was combined with peoplecentrism more often on Pulse than on any other talk show. The team of candidate Boiko, consistently adhering to pro-Russian rhetoric since the creation of his "Opposition Platform For Life" political party (OPZZh), was reproducing the narrative that any candidate is better than Poroshenko, any parliament is better than the current one, etc. Sometimes, in their attempts to demonize the fifth president of Ukraine, Boiko's representatives even forgot to praise "the people" and instead scolded some of them: "It is clear why we do not support Poroshenko. We do not support him a priori because normal people cannot support him" (Pulse, episode 2, 16 Apr. 2019, $2: 22: 46) .4$

Likewise, on Echo of Ukraine-a talk show loyal to Poroshenko-crisis rhetoric was combined with people-centrism more often than on any other talk show. Poroshenko's opponent in the second round was Zelens'kyi-a political outsider without any experience in public administration. Thus, the strategy was to convince voters that the risks of having an incompetent president were too high. Here is an example of the typical Poroshenko narrative: "I want to remind everyone of the price that Ukrainians have paid - not only this generation - for us to be engaged in the process of statebuilding. And I ask, I pray that you take this unique and extremely important

\footnotetext{
${ }^{4}$ All translations are my own.
} 
choice very responsibly. We won't get another chance if we lose this battle now" (Freedom of Speech, episode 1, 26 Mar. 2019, 00:42:49).

In sum, Figure 3 demonstrates that the dominance of one or another type of populism on Ukrainian political talk shows generally reflects the ownership structure on the television market, which means that the dynamics of media-political parallelism extend to populist communication, as well (Khabyuk). This contributes to the fragmentation of socio-political television in Ukraine and requires journalists, experts, and other intermediaries working amid the populism to employ diverse strategies while moderating talk shows and when dealing with populist actors.

The last statistic considered in this study relates to the question of who disseminated the PCAs on the studied talk show episodes. As can be seen from Figure 4, populist communication remains the politicians' prerogative. This is especially evident on Freedom of Speech, where the roles of the talk show moderator and most of the guests were minimized. At the same time, on Echo of Ukraine and Right to Power the talk show hosts and, to a lesser extent, the journalists were also responsible for a considerable share of the populist communication. The "Other" category, which is notable in the cases of Echo of Ukraine and Pulse, included experts, former politicians, and civil society representatives, most of whom were also somehow affiliated with one or another candidate or political force.

Figure 4: Sources of populist communication on each talk show, \% (n=283).

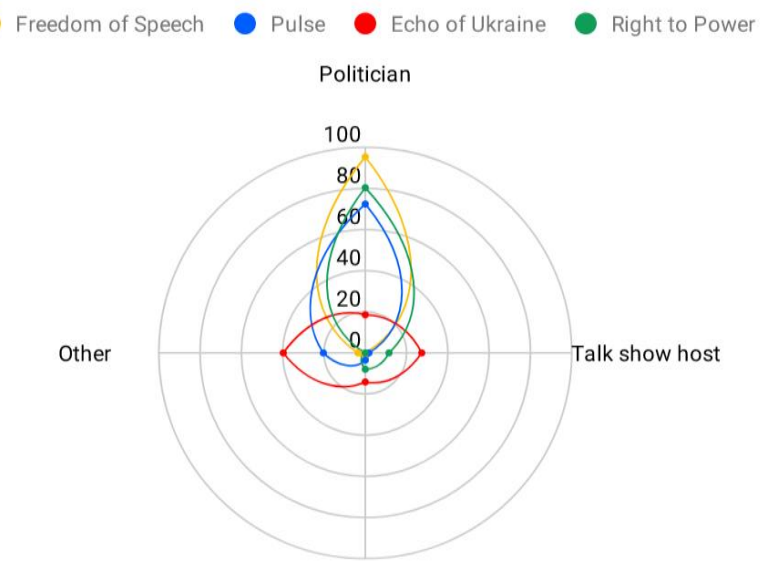

Journalist

In the next section, the question of journalists' contributions to populism dissemination will be discussed in greater detail, as it signalizes 
the potential lack of their professional autonomy. However, before proceeding further, it needs to be said that Figure 1 and Figure 2 do not consider the PCAs contained in the visual-graphical elements of the first episode of Pulse-namely, the dynamic news ticker. I view this issue important enough to mention here as it (1) reveals another option for disseminating populism on television talk shows; (2) provides an example of a case when populism is preconditioned by media producers at the organizational level; and (3) offers an instance of PCAs that cannot be challenged by any of the talk show participants because of their visibility to the talk show viewers only.

To elaborate, the ticker in question consisted of twenty textual messages, transmitted linearly one after another at the bottom of the screen. Its full broadcast cycle was five minutes; after this, the messages started over again. The cycle included sixteen news messages and four quotes, three of which belonged to Medvedchuk, a person who is reported to influence the channel's content. Two of his three quotes contained populist elements:

"NAFTOGAZ [a state-owned national oil and gas company subordinated to the government of Ukraine] has admitted selling gas to Ukrainians at astronomically inflated prices-Medvedchuk." (Pulse, episode 1, 26 Mar. 2019)

"Negotiations concerning a 25\% reduction in gas prices have shown what can be achieved when negotiating in the interest of people, not in the interest of pro-government businessmen [sic] who make money at the expense of people's impoverishment-Medvedchuk." (Pulse, episode 1, 26 Mar. 2019)

As can be seen, both statements are examples of anti-elitist populism. During the broadcast, each statement was shown forty-eight (!) times. In total, the two messages were present on the screen for almost half an hour and were certainly likely to affect the attitudes of the audience (for psychological mechanisms behind the process, see Fitzgerald and Baird). The case of Pulse demonstrates the possibilities for transmitting populism that are provided by the genre of a television talk show. This includes but is not limited to graphical elements, studio polls, and applause patterns. All these elements deserve attention, both from the media workers producing the content and from the scholars researching it. 


\section{Reactions to Populism on Ukrainian Political Talk Shows}

I shall now proceed to the question of how populism was reflected by the TV program participants. Figure 6 presents 145 reactions to populist communication, each of which was attributed to one of the two roles (gatekeeping or interpreting) and one of the four sub-roles (gate closure, positive evaluation, negative evaluation, or critical evaluation). The graph shows how the sub-roles varied on different talk shows and which sub-roles were employed by different groups of actors. The red figures above each bar indicate the total number of reactions for a certain group of actors on each talk show. Because Figure 6 operates with absolute numbers, it does not consider the duration of the talk show episodes and the number of PCAs on them. That is why the graph serves exclusively for comparison within the talk shows and not across them.

\section{Gatekeeping}

As we see from Figure 6, gatekeeping is a widespread technique for minimizing populism. This role is mainly the privilege of the studio hosts; however, depending on the talk show format, other groups of actors may also become involved in a gatekeeping process. For example, Pulse is arranged on the principle of an open microphone. The guests do not need moderators' permission to speak-they can interrupt each other and speak considerably longer than their colleagues if they manage to conquer the floor. This increases the chances that guest politicians could succeed in exercising a gatekeeping role. At the same time, the open mic format has certain drawbacks. First, it often leads to a chaos in the studio, which increases the talk show ratings but offsets the value of the discussion and promotes populism. Another disadvantage is that hosts have to spend a lot of effort and airtime pacifying their talk show guests. This leads to an increase in "technical gatekeeping," so to speak, which hinders populist communication but does not actually target it. The dominance of such "technical" gatekeeping partly levels the populism-associated activity of the hosts on Pulse. 


\section{Figure 5: Functions relating to populism carried out by actors on talk shows $(n=145)$.}

\section{$\square$ Gate Opening $\quad \square$ Gate Closure $\quad \square$ Positive Evaluation $\square$ Negative Evaluation $\quad \square$ Critical Evaluation}

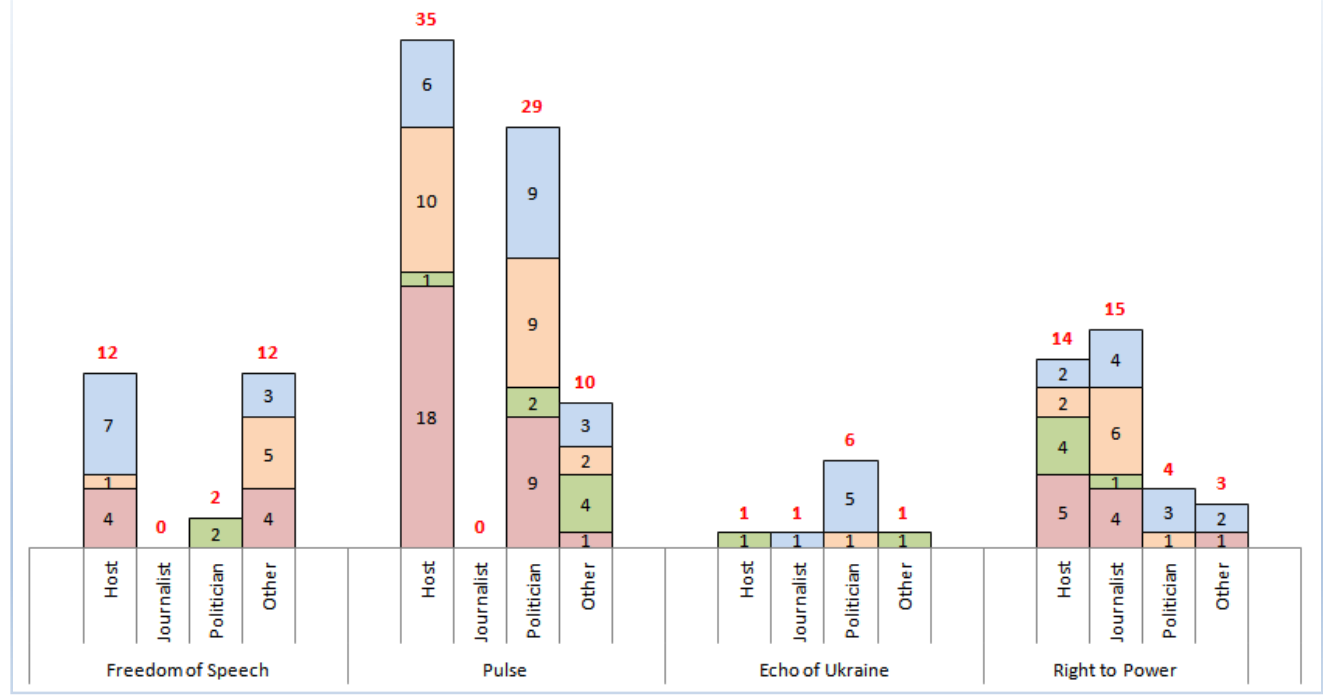

When journalists are among a talk show's main guests, they are also likely to join the moderators in exercising gatekeeping. For example, on Right to Power, journalists often sit on one side of the studio in front of the politicians and ask them questions along with the talk show moderator. Such setting forces both groups of actors to select their words with more caution. Another distinctive feature of Right to Power is that politicians have limited time in which to give speeches-just two slots, at the beginning and at the end of the program, and most of the time they are answering specific questions from journalists and moderators. This format implies journalistic opposition to politicians spreading unwelcome messages, including populist ones, and provides better opportunities for gatekeeping.

The absence of gatekeeping, especially on the part of the moderator(s), is an alarming sign because it means essentially that populism would not be challenged on a particular talk show or a given episode. For example, Freedom of Speech host Vadym Karpiak failed to carry out a gatekeeping role before the first election round, and this lapse coincided with a high share and intensity of populist communication on the program. In fact, of all the studied reactions that inhibited populism, only four occurred in the first episode of Freedom of Speech, and not one of them was directed at 
Poroshenko, who was their main disseminator. By comparison, in the second episode Zelens'kyi's representative Oleksandr Danyliuk disseminated nine populist messages and received ten restrictive reactions (most of them from the host). A total absence of gatekeeping was observed on Echo of Ukraine, where Matvii Hanapol's'kyi did not challenge populist statements while moderating the program.

\section{Interpreting}

Figure 6 shows that the interpretive role was exercised by all groups of actors and was generally more common than the gatekeeping role. Interpreting by politicians occurred when there was direct contact between opposing political groups - for example, in the first episode of Pulse. As for moderators and journalists, in the ideal scenario only critical evaluations are expected from them, because positive or negative evaluations may indicate bias. Nevertheless, on both Pulse and Right to Power media representatives frequently resorted to polar emotional evaluations, not leaving enough room for constructive criticism.

Positive and negative evaluations, which are basically various forms of approval and disapproval, can be both verbal and non-verbal. Non-verbal reactions are of interest, as they are specific to television and may be seen immediately during a speaker's performance. On Right to Power, a lot of negative reactions to populism were shown non-verbally. They included irony, weary sighs, chuckling, facial expressions, and so on. Sometimes, nonverbal communication alone was enough to create an aura of skepticism around certain politicians, which contributed to the reduced credibility of their words among the audience. The producers of Right to Power evidently intended to emphasize non-verbal reactions; during the discussions, the screen was often divided in two, showing close-ups of the opponents' faces.

The problem with both verbal and non-verbal negative reactions is that they are quite selective. Our data show that talk show participants tended to be more provocative and disrespectful toward low-ranking politicians and unpopular candidates ("political losers," "technical" [diversionary] candidates), while authoritative politicians usually faced a less toxic environment. Thus, the candidate Poroshenko, the incumbent president at the time of the campaign, did not receive a frankly hostile reception in any of the talk show studios. Even on Pulse, the guests who kept insulting Poroshenko after he left were absent in the studio during his presence and appeared only for the second part of the program. In the best-case scenario, such negative evaluations should be replaced by critical ones, as they are more efficient in challenging populism and do not create in- and out-groups in the studio (de Vreese). 
As for positive evaluations of populism, they were present albeit quite rare on all of the studied talk shows. The usage of positive evaluations by politicians usually indicates the existence of certain political clusters in the studio. On Freedom of Speech, the presence of positive evaluations was connected to a lack of balance of opinions. In particular, Poroshenko not only fielded convenient questions but also enjoyed meritorious nods and other manifestations of approval. The same was observed on Echo of Ukraine, which scored the highest proportion of positive evaluations. On Pulse, positive evaluations were noted as Boiko and OPZZh-connected figures benefited from broader time limits, indulgence on the part of moderators, and weak and defensive opponents. The OPZZh affiliates were much more united than other guests in the studio and repeatedly encouraged each other, including when populism was disseminated. In general, positive evaluations of populism were in line with the political parallelism trends highlighted by Burmahin and colleagues.

\section{Initiating}

Unlike the roles listed above, the initiation of populism applies only to the media representatives - in our case, the talk show moderators and journalists. This subset of actors deserves special attention, as in many countries the mass media enjoy high levels of citizens' trust compared to other social institutions, and Ukraine in 2019 was no exception (see Razumkov Tsentr). It means that by initiating populist messages media workers do populists a big favour since the spread of political messages by supposedly unbiased actors helps to overcome resistance to persuasion and reduces the general level of criticality of the audience (Moyer-Guse and Nabi).

As can be seen from Figure 4, journalists and moderators were active in initiating populism mainly on Echo of Ukraine and, to a lesser extent, Right to Power. All the identified cases of initiating can be divided into three conceptual groups according to their purpose: (1) for image-building; (2) for asking questions; and (3) for delivering messages. The groups were derived inductively after coding the data collected under category $4 \mathrm{C}$. This step was not reflected in the methodology since it only came up during the interpretation phase and is referred to here for the sake of a more structured presentation.

Initiating populism for image-building is the most "innocent" of the three; however, it may definitely serve as a good foundation for the subsequent dissemination of populism. The type in question includes cases when talk show moderators or invited journalists try to establish contact with the audience through emphasizing their proximity and building an image of a "one-of-us guy," which is often done through the appeal to "the 
people." Later, such an image can be successfully used to disseminate populism. For instance, a Right to Power host, Nataliia Moseichuk, tends to comment on serious and complicated topics by telling personal stories featuring her, her friends, family members, and neighbours. Sometimes these stories explicitly criticize or support a particular policy. Such stories have more in common with kitchen talk than with political discussion. They prove or disprove nothing but at the same time raise "the people" narrative once again, simplify the socio-political discourse, and nurture an atmosphere where emotions are more welcome than persuasive arguments. On Echo of Ukraine, its host Matvii Hanapol's'kyi also tended to employ certain tricks that influenced how he was perceived by viewers. Hanapol's'kyi frequently turns to humour, which is reported to be an effective tool of credibility building (Vraga et al. 9). On one occasion he even complained about feeling very sick and used this pretext to interrupt other speakers: "Excuse me, I am sick, have pity on me, one minute, I want to ask you something .... Please, listen to me because I will fall down here right now and that will be it. I don't feel well; I have to hold on for another fifty minutes; I have a fever and everything ..." (Echo of Ukraine, episode 1, 29 Mar. 2019, 02:36:58). These examples of appealing to viewers' emotions are not directly related to populism and are likely to have been employed in order to increase the talk show ratings (Krämer). However, such behavioural strategies facilitate rather than prevent populist communication through reducing rationality.

Initiating populism for asking questions is probably the most common type. Both moderators and journalists tend to ask questions on behalf of the people. They use such wording as "millions of people want to know" or "at least with respect to our audience." Apart from leading to the effects explained above (establishment of a populist-like contact with viewers), this role type also appeals to "the people" explicitly; hence it provokes speakers into answering in a populist manner. Consider the following example from Right to Power, where it was a politician who criticized the populist rhetoric of a journalist and not the other way around:

PCA by the journalist: "You are the owner of the elite Bukovel Resort. Perhaps only in France are accommodations more expensive. One needs at least ten times the minimum wage in Ukraine to stay there. What have you done as a deputy and a presidential candidate so that your resort would be more accessible for the middle class?"

Response from the politician: "Bukovel exists in the market economy .... There are thousands of people staying there every day, and all of them are definitely not oligarchs.... [There are many ways to reduce the cost of a holiday in Bukovel by] staying outside the resort area or coming during low season." (Right to Power, episode 1, 28 Mar. 2019, 03:08:50-03:10:00) 
Being even more critical of the journalist's question, one might argue that presidential candidate status has nothing to do with the prices in the ski resort and that elite resorts, just as five-star hotels, are not meant for the middle class. Questions such as this one should be avoided by media workers because they create an artificial tension between "the ordinary people" and "wealthy politicians" and, as a result, nurture populist sentiments among talk show audiences.

Finally, according to the parameters of the "initiating for delivering messages" type, media representatives disseminate populism in order to convey specific opinionated messages that are often political in their nature. Echo of Ukraine offers a textbook example of this type of populism initiation. On the eve of the second round, when Zelens'kyi was overtaking Poroshenko according to all the sociological polls, Hanapol's'kyi consistently tried to deprive Zelens'kyi of his connection with the people, using something that I shall call reverse populism. Instead of saying that Poroshenko was close to the people (populism), Hanapol's'kyi was arguing that Zelens'kyi was far from them (reverse populism). Here is just one of the numerous documented instances:

PCA by Hanapol's'kyi (talking to studio audience): “He's not speaking to you and he is right in that because you are all suckers .... Just think, he went to Macron, he needs to talk. But not with you because you are nobody. You do not deserve a conversation with him. [His message to you is:] 'First you vote for me ... and then I will talk to you ... maybe."' (Echo of Ukraine, episode 2, 12 Apr. 2019, 01:26:14)

As can be seen, Hanapol's'kyi pretended to be Zelens'kyi and offended the people on his behalf. Specifically, he created an outgroup-people who did not explicitly support Zelens'kyi-and tried to make them angry in order to mobilize them to vote for Poroshenko. Hanapol's'kyi combined populism and hate speech. In the very same episode, he said to the studio guests: "I am deliberately annoying you. Listen to me-I want you to be as angry as dogs!" (Echo of Ukraine, episode 2, 12 Apr. 2019, 00:35:44) One might argue that Hanapol's'kyi, known for his eccentricity, is not representative of the overall trends on the channel. However, this study focused on political talk shows in a specific time frame, and Hanapol's'kyi hosted the channel's most important and watchable program-which, unlike most of the other weekly talk shows, was broadcast Monday to Friday during prime time. Hanapol's'kyi was deliberately positioned as the face of Priamyi by the TV channel's management and was repeatedly viewed as one of the key figures on Ukrainian political television ahead of the election (see Kulias). 


\section{CONCLUSION}

This study systematically examined populist communication on Ukrainian television political talk shows in a specific time frame-namely ahead of the presidential election in 2019. Even this tentative inquiry demonstrates that the Ukrainian case provides fertile ground for increasing the theoretical understanding of modern populism as a political and communicative phenomenon. Populist discourse was identified on all of the studied talk shows and its share varied from $7.4 \%$ of the airtime in the first episode of Right to Power to $23.8 \%$ of the airtime in the first episode of Freedom of Speech. On average, viewers of the studied episodes were exposed to two populist communication acts every ten minutes, not counting the populist messages televised on the news tickers. This finding confirms that in their current form Ukrainian political talk shows provide quite a favourable environment for populist dissemination, constituting a serious challenge for media workers and media consumers.

The amount of populism on the talk shows was to a large extent preconditioned by the talk show format and organization of the given episodes. For example, a large share of populism was associated with the lack of opinion-balance in the studio, passiveness and/or bias of the moderators, and passiveness or absence of journalists. Furthermore, different talk show formats implied different conditions for the dissemination and moderation of populism. For instance, strict rules concerning duration and order of the speakers' presentations seemed to reduce the proportion of populism (see Right to Power), while the open microphone format offered good opportunities for inclusive gatekeeping yet limited the hosts' authority (see Pulse).

The analyzed data also revealed that unlike in many other European countries, where populist discourse is relatively homogeneous in terms of its content and disseminators, Ukrainian populism is more diverse and decentralized. Particularly, different types of populism prevailed in the studied talk shows: Right to Power scored highest in empty populism, Pulse was highest in anti-elitist populism, and Echo of Ukraine was highest in emergency populism. Overall, the dominance of one or another type of populism reflected the ownership structures of the sampled television channels, testifying that media-political parallelism extends its impact to populist communication. This means that there are many "populisms" in Ukraine. Depending on the consumed media outlet(s), the audience segments face different communication challenges. This contributes not only to the ideological fragmentation of the Ukrainian audience but also to its emotional fragmentation, as different types of populism trigger diverse affective responses: empty populism leads to in-group favouritism, antielitist populism provokes out-group blame and resentment, and emergency 
populism causes anxiety and fear (Demertzis). All these nuances should be considered by talk show producers, moderators, journalists, and any other actors whose normative role suggests restricting populism and mitigating its negative effects.

The study has also examined how media workers (moderators and invited journalists), as well as other talk show participants, exercised the roles of gatekeeping and interpreting with respect to instances of populist communication. On the one hand, the data indicate that the studied talk shows did not offer politicians a completely unregulated environment on the eve of the election: in general, 283 populist communication acts identified during our analysis received 129 restrictive and only 16 supportive reactions. On the other hand, the efforts applied to the restriction of populism did not seem to have any connection with its share or intensity on a particular program. When present, opposition to populism was better explained by some other situational factors, such as the political mood in the studio, media-political parallelism, the talk show format, and so on. This indicates the prevalence of "technical" and "unintended" handling of populism and decreases the value of gate closure or negative and critical evaluations of populism. Besides, the data also showed that the role of journalists as intermediaries between populism and the audiences requires reconsideration. On all the studied talk shows, except Right to Power, journalists were either absent or extremely passive and marginalized. This made constructive opposition between politicians and journalists impossible during the broadcast and hindered the professional potential of the latter to challenge populist communication.

Finally, the study also examined the role of media workers in initiating and/or disseminating populism during the talk shows. The collected material allowed us to conceptualize three "risk zones" where journalists might consciously contribute to spreading populism: while building up selfimage (or image of the channel), asking questions, and delivering opinionated messages.

The conducted research suggests numerous directions for further inquiry. It would be especially valuable to determine the following: which thematic issues constitute the core of Ukrainian populist discourse(s); how successful diverse actors are in dealing with diverse types of populist communication; and what differences exist between populism types and how it is handled on commercial versus public television channels. In addition, the Ukrainian case of populism deserves examination in a comparative perspective-for example, in the pool of states undergoing transition, like Bosnia and Herzegovina, states influenced by their totalitarian past, like Croatia, states with media systems lacking structural autonomy, like Hungary, and in the Eastern European context in general. 
Works Cited

Aalberg, Toril, et al., editors. Populist Political Communication in Europe. Routledge, 2017.

Albertazzi, Daniele, and Duncan McDonnell. "Introduction: The Sceptre and the Spectre." Twenty-First Century Populism: The Spectre of Western European Democracy, edited by Daniele Albertazzi and Duncan McDonnell, Palgrave Macmillan, 2008, pp. 1-11.

Aslanidis, Paris. "Is Populism an Ideology? A Refutation and a New Perspective." Political Studies, vol. 64, no. 1_suppl, April 2016, pp. 88-104. DOI: 10.1111/14679248.12224

Bischof, Daniel, and Roman Senninger. "Simple Politics for the People? Complexity in Campaign Messages and Political Knowledge." European Journal of Political Research, vol. 57, no. 2, May 2018, pp. 473-95. DOI:10.1111/1475-6765.12235

Breeze, Ruth. "Positioning 'the People' and Its Enemies: Populism and Nationalism in AfD and UKIP." Javnost - The Public, vol. 26, no. 1, Jan. 2019, pp. 89-104. DOI:10.1080/13183222.2018.1531339

Burmahin, O., et al. The Final Report on Independent Monitoring of Media Coverage in the Presidential Election Campaign in Ukraine. Council of Europe, 2019, http://cje.org.ua/sites/default/files/library/1st\%20interim\%20report ENG F INAL.pdf. Accessed 25 Apr. 2021.

Deegan-Krause, Kevin, and Tim Haughton. "Toward a More Useful Conceptualization of Populism: Types and Degrees of Populist Appeals in the Case of Slovakia." Politics \& Policy, vol. 37, no. 4, Aug. 2009, pp. 821-41. DOI:10.1111/j.17471346.2009.00200.x

Demertzis, Nicolas. "Emotions and Populism." Emotion, Politics and Society, edited by Simon Clarke et al., Palgrave Macmillan UK, 2006, pp. 103-22.

Deuze, Mark. "What Is Journalism? Professional Identity and Ideology of Journalists Reconsidered." Journalism: Theory, Practice \& Criticism, vol. 6, no. 4, Nov. 2005, pp. 442-64. DOI:10.1177/1464884905056815

De Vreese, Claes H. "Political Journalism in a Populist Age." Shorenstein Center on Media, Politics and Public Policy, Dec. 2017, https://shorensteincenter.org/political-journalism-populist-age/. Accessed 25 Apr. 2021.

Donahue, G. A., et al. “Gatekeeping: Mass Media Systems and Information Control.” Current Perspectives in Mass Communication Research, edited by F. G. Kline and P. J. Tichenor, SAGE, 1972, pp. 41-70.

Ernst, Nicole, et al. "Favorable Opportunity Structures for Populist Communication: Comparing Different Types of Politicians and Issues in Social Media, Television and the Press." The International Journal of Press/Politics, vol. 24, no. 2, 2019, pp. 165-88. DOI:10.1177/1940161218819430

Esser, Frank, et al. "Populism and the Media: Cross-National Findings and Perspectives." Populist Political Communication in Europe, edited by Toril Aalberg et al., Routledge, 2017, pp. 365-80.

Filc, Dani. "Post-Populism: Explaining Neo-Liberal Populism through the Habitus." Journal of Political Ideologies, vol. 16, no. 2, June 2011, pp. 221-38. DOI:10.1080/13569317.2011.575685 
Fitzgerald, Jennifer, and Vanessa A. Baird. "Taking a Step Back: Teaching Critical Thinking by Distinguishing Appropriate Types of Evidence." Political Science and Politics, vol. 44, no. 3, 2011, pp. 619-24. DOI: 10.1017/S1049096511000710

Freeden, Michael. Ideologies and Political Theory: A Conceptual Approach. Clarendon Press, 1998.

Goffman, Erving. Frame Analysis: An Essay on the Organization of Experience. Northeastern UP, 1986.

Groshek, Jacob, and Karolina Koc-Michalska. "Helping Populism Win? Social Media Use, Filter Bubbles, and Support for Populist Presidential Candidates in the 2016 US Election Campaign." Information, Communication \& Society, vol. 20, no. 9, Sept. 2017, pp. 1389-407. DOI:10.1080/1369118X.2017.1329334

Haller, André. "How to Deal with the Black Sheep? An Evaluation of Journalists' Reactions towards Intentional Self-Scandalization by Politicians." Journal of Applied Journalism \& Media Studies, vol. 4, no. 3, Nov. 2015, pp. 435-51. DOI:10.1386/ajms.4.3.435_1

Hallin, Daniel C., and Paolo Mancini. Comparing Media Systems: Three Models of Media and Politics. Cambridge UP, 2004.

Internews Ukraine. Media Consumption Survey in Ukraine 2018. Internews.org, 2018, https://www.internews.org/sites/default/files/2018-09/2018-

MediaConsumSurvey eng FIN.pdf. Accessed 25 Apr. 2021.

Jagers, Jan, and Stefaan Walgrave. "Populism As Political Communication Style: An Empirical Study of Political Parties' Discourse in Belgium." European Journal of Political Research, vol. 46, no. 3, May 2007, pp. 319-45. DOI:10.1111/j.14756765.2006.00690.x

Khabyuk, Oleksiy, editor. Public Service Broadcasting: A German-Ukrainian Exchange of Opinions. Lit, 2011.

KIIS (Kyiv International Institute of Sociology). Sources of Information, Media Literacy and Russian Propaganda: The Results of An All-Ukrainian Public Opinion Poll. Analytical Meport, March 2019, https://detector.media/doc/images/news/archive/2016/164308/AReport M edia Feb2019 v2.pdf. Accessed 25 Apr. 2021.

Krämer, Benjamin. "Media Populism: A Conceptual Clarification and Some Theses on Its Effects." Communication Theory, vol. 24, no. 1, Feb. 2014, pp. 42-60. DOI: $10.1111 /$ comt.12029

Kulias, Ihor. "Vsi materialy avtora." Detektor Media, Vybory $i$ ZMI, https://vybory.detector.media/author/ihor-kulyas/. Accessed 23 May 2020.

Kuzio, Taras. "Impediments to the Emergence of Political Parties in Ukraine." Politics, vol. 34, no. 4, Dec. 2014, pp. 309-23. DOI:10.1111/1467-9256.12067

Laclau, Ernesto. "Populism: What's in a Name?" Populism and the Mirror of Democracy, edited by F. Panizza, Verso, 2005, pp. 32-49.

Lankina, Tomila, et al. "Authoritarian and Democratic Diffusion in Post-Communist Regions." Comparative Political Studies, vol. 49, no. 12, Oct. 2016, pp. 1599-629. DOI:10.1177/0010414016628270

Lokot, Tetyana. "Public Networked Discourses in the Ukraine-Russia Conflict: 'Patriotic Hackers' and Digital Populism." Irish Studies in International Affairs, vol. 28, 2017, p. 99. DOI:10.3318/isia.2017.28.9

Mayer, Frederick. Narrative Politics: Stories and Collective Action. Oxford UP, 2014. 
Mazzoleni, Gianpietro. "Populism and the Media." Twenty-First Century Populism. The Spectre of Western European Democracy, edited by Daniele Albertazzi and Duncan McDonnell, Palgrave Macmillan, 2008, pp. 49-66.

Moffitt, Benjamin, and Simon Tormey. "Rethinking Populism: Politics, Mediatisation and Political Style." Political Studies, vol. 62, no. 2, June 2014, pp. 381-97. DOI:10.1111/1467-9248.12032

Moyer-Guse, Emily, and Robin L. Nabi. "Explaining the Effects of Narrative in an Entertainment Television Program: Overcoming Resistance to Persuasion." Human Communication Research, vol. 36, no. 1, Jan. 2010, pp. 26-52. DOI:10.1111/j.1468-2958.2009.01367.x

Mudde, Cas. "The Populist Zeitgeist." Government and Opposition, vol. 39, no. 4, 2004, pp. 541-63. DOI: 10.1111/j.1477-7053.2004.00135.x

Norris, Pippa, and Ronald Inglehart. Cultural Backlash: Trump, Brexit and Authoritarian Populism. Cambridge UP, 2018.

Ojala, Markus, and Reeta Pöyhtäri. "Watchdogs, Advocates and Adversaries: Journalists' Relational Role Conceptions in Asylum Reporting." Media and Communication, vol. 6, no. 2, June 2018, p. 168. DOI:10.17645/mac.v6i2.1284

Palinkas, Lawrence A., et al. "Purposeful Sampling for Qualitative Data Collection and Analysis in Mixed Method Implementation Research." Administration and Policy in Mental Health and Mental Health Services Research, vol. 42, no. 5, Sept. 2015, pp. 533-44. D0I:10.1007/s10488-013-0528-y

Patton, Michael Quinn. Qualitative Research and Evaluation Methods. 3rd ed., Sage Publications, 2002.

Razumkov Tsentr. "Riven' doviry do suspil'nykh instytutiv ta elektoral'ni oriientatsii hromadian Ukrainy." Razumkov Tsentr, 20 Feb. 2019, http://razumkov.org.ua/napriamky/sotsiologichni-doslidzhennia/rivendoviry-do-suspilnykh-instytutiv-ta-elektoralni-oriientatsii-gromadian-ukrainy. Accessed 25 Apr. 2021.

Reinemann, Carsten, et al. Communicating Populism: Comparing Actor Perceptions, Media Coverage, and Effects on Citizenship in Europe. Routledge, 2019.

Rooduijn, Matthijs. "The Nucleus of Populism: In Search of the Lowest Common Denominator." Government and Opposition, vol. 49, no. 4, Oct. 2014, pp. 573-99. DOI:10.1017/gov.2013.30

Ryabinska, Natalya. Ukraine's Post-Communist Mass Media: Between Capture and Commercialization. Ibidem Verlag, 2017.

Schreier, Margrit. Qualitative Content Analysis in Practice. SAGE, 2012.

Shkarpova, Olena, et al. "Teoriia brekhni: Pershyi reitynh populistiv i brekhuniv v ukrains'kii politytsi vid VoxUkraine." VoxUkraine, 2017, https://voxukraine.org/longreads/lie-theory/index-ua.html. Accessed 25 Apr. 2021.

Shoemaker, Pamela J., and Tim P. Vos. Gatekeeping Theory. Routledge, 2009.

Sukha, Nadiia. "Vkhodiat' i vykhodiat': iak deputaty fraktsii ta partii miniaiut'." Ukrainska pravda, 26 July 2018, https://vybory.pravda.com.ua/articles/2018/07/26/7149699/. Accessed 25 Apr. 2021.

Verkhovna Rada Ukrainy. Narodni deputaty Ukrainy. Verkhovna Rada Ukrainy, http://w1.c1.rada.gov.ua/pls/site2/p_deputat_list. Accessed 29 May 2019. 
Vraga, Emily K., et al. "The Correspondent, the Comic, and the Combatant: The Consequences of Host Style in Political Talk Shows." Journalism \& Mass Communication Quarterly, vol. 89, no. 1, March 2012, pp. 5-22. DOI:10.1177/1077699011428575

Wettstein, Martin, et al. "News Media As Gatekeepers, Critics, and Initiators of Populist Communication: How Journalists in Ten Countries Deal with the Populist Challenge." The International Journal of Press/Politics, vol. 23, no. 4, Oct. 2018, pp. 476-95. DOI:10.1177/1940161218785979

Weyland, Kurt. "Clarifying a Contested Concept: Populism in the Study of Latin American Politics." Comparative Politics, vol. 34, no. 1, Oct. 2001, pp. 1-22. DOI:10.2307/422412.

---. "Neoliberal Populism in Latin America and Eastern Europe." Comparative Politics, vol. 31, no. 4, July 1999, pp. 379-401. DOI:10.2307/422236

Whitmore, Sarah. Political Party Development in Ukraine. Helpdesk Research Report, GSDRC, 2014, http://gsdrc.org/docs/open/hdq1146.pdf. Accessed 25 Apr. 2021. 